\title{
PENGARUH KONSEP DIRI, SIKAP SISWA PADA MATEMATIKA, DAN KECEMASAN SISWA TERHADAP HASIL BELAJAR MATEMATIKA
}

\author{
Leonard dan Supardi U.S. \\ FT dan FMIPA Universitas Indraprasta PGRI (e-mail: leonard@unindra.net;
}

HP: 081382939050)

\begin{abstract}
Effects of Students' Self-Concept, Behavior towards Mathematics, and Anxiety on Mathematics Learning Achievement. This study aims to investigate effects of students' self-concept, behavior towards mathematics, and anxiety on the mathematics learning achievement using the Path Analysis. The results show that: (1) there is a positive direct effect of positive self-concept on students' mathematics achievement; 2) there is no indirect effect of self-concept on students' mathematics achievement through anxiety; 3) there is no indirect effect of students' behavior towards mathematics on students' mathematics achievement through anxiety; 4) there is a negative direct effect of anxiety on students' mathematics achievement; and 5) there is a positive direct effect of self-concept on students' behavior towards mathematics.
\end{abstract}

Keywords : self-concept, students' behavior towards mathematics, anxiety, learning achievement, path analysis

\section{PENDAHULUAN}

Pada hakikatnya, pendidikan merupakan kegiatan yang telah berlangsung seumur dengan manusia. Artinya, sejak adanya manusia telah terjadi usaha-usaha pendidikan dalam rangka memberikankemampuan kepadasubjek didik untuk dapat hidup dalam masyarakat dan lingkungannya. Dengan diberikan pendidikan, seorang anak didik sanggup untuk berbuat dan bertindak sebagai manusia yang berkepribadian sosial. M.J. Langelveld seperti dikutip oleh Supardi \& Leonard mengatakan, "Pendidikan adalah setiap usaha, pengaruh, perlindungan dan bantuan yang diberikan kepada anak didik yang bertujuan pada pendewasaan anak itu." Jadi, pendidik- anmerupakanproses pembelajaran yang output-nya berupa hasil belajar.

Hasil belajar ini ditentukan oleh banyak faktor, antara lain: faktor guru, lingkungan sekolah, lingkungan tempat tinggal, cara belajar siswa, fasilitas belajar yang digunakan, faktor internal siswa, dan lain sebagainya. Akan tetapi, seorang siswa yang telah menyadari tugasnya sebagai seorang pembelajar seharusnya dapat menggunakan faktorfaktor yang ada untuk memaksimalkan hasil belajarnya. Hasil belajar matematika siswa dapat dilihat apabila tujuantujuan pembelajaran yang telah ditetapkan dapat dicapai oleh siswa, dan sebaliknya apabila sebagian besar siswa tidak dapat mencapai tujuan-tujuan dari 
pembelajaran berarti hasil pembelajaran tidak tercapai.

Mata pelajaran matematika dianggap sebagian siswa sebagai mata pelajaran yang sukar dan biasanya belajar matematika memerlukan konsentrasi tinggi. Saat ini, masih banyak siswa yang mengalami kesulitan belajar matematika. Mereka menganggap matematika suatu pelajaran yang menakutkan, membosankan, dan menjadi beban bagi siswa karena bersifat abstrak, penuh dengan angka dan rumus. Selain itu, masih adanya sistem belajar yang menyamaratakan kemampuan siswa. Saat siswa belum menguasai materi dasar, sudah ditambah dengan materi lain. Para siswa pun cenderung tidak menyukai matematika karena dianggap sulit terutama dalam menyelesaikan soal-soal yang diberikan oleh guru matematika. Apalagi jika guru yang mengajar matematika sulit dipahami dalam pembawaan materi di dalam kelas sehingga keadaan ini menambah ketidaksukaan siswa pada matematika, dan bahkan akhirnya membenci guru matematikanya.

Pada dasarnya hasil belajar matematika siswa dipengaruhi oleh beberapa faktor, diantaranya sikap siswa pada matematika, konsep diri dan kecemasan siswa dalam belajar; selain faktor-faktor eksternal lainnya. Sikap adalah pernyataan-pernyataan evaluatif baik yang diinginkan atau yang tidak diinginkan mengenai objek, orang atau peristiwa. Sikap mencerminkan bagaimana seseorang merasakan sesuatu (Robbins, 2006:93). Setiap individu dalam melakukan aktivitasnya akan didasarkan atas sikapnya tentang aktivitas yang akan dilaksanakannya. Sikap umumnya akan mencerminkanbagaimana seseorangmerasakan sesuatu. Misalnya, jika seorang siswa mengatakan bahwa "saya menyukai pelajaran matematika", berarti dia sedang mengungkapkan sikapnya tentang mata pelajaran matematika tersebut (Robbins, 2006:121). Sikap berhubungan dengan kesiagaan mental seperti rumusan yang menyatakan bahwa sikap adalah kesiapsiagaan mental yang diorganisasi lewat pengalaman, yang mempunyai pengaruh tertentu kepada tanggapan seseorang terhadap orang, objek dan situasi yang berhubungan dengannya (Gibson, 1990: 68).

Kecemasan biasanya akan timbul jika individu menghadapi situasi yang dianggapnya mengancam dan menekan. Dalam kondisidimana rasa cemas menghinggapi pikiran seseorang, tentunya orang tersebut akan berpikiran atau berangggapan yang negatif terhadap dirinya sendiri. Taylor (1995) mengatakan bahwa kecemasan ialah suatu pengalaman subjektif mengenai ketegangan mental yang menggelisahkan sebagai reaksi umum dan ketidakmampuan menghadapi masalah atau adanya rasa aman. Perasaan yang tidak menyenangkan ini umumnya menimbulkan gejalagejala fisiologis (seperti gemetar, berkeringat, detak jantung meningkat, dan lain-lain) dan gejala-gejala psikologis (seperti panik, tegang, bingung, tak dapat berkonsentrasi, dan sebagainya). Kecemasan sampai pada batas tertentu merupakan hal yang normal bagi setiap orang. Mungkin seseorang merasa khawatir akan sesuatu atau orang lain karena ia pernah mengalami hal yang tidak menyenangkan pada kejadian serupa dimasa lampau. Kecemasan sam- 
pai pada batas tertentu merupakan hal yang normal bagi setiap orang. Mungkin seseorang merasa khawatir akan sesuatu atau orang lain karena ia pernah mengalami hal yang tidak menyenangkan pada kejadian serupa di masa lampau. Kecemasan dalam taraf "normal" dapat berfungsi sebagai sistem alarm yang memberikan tanda-tanda bahaya bagi seseorang yang mengalaminya untuk dapat lebih siap menghadapi keadaan yang akan muncul.

Konsep diri merupakan tanggapan individu yang sehat terhadap diri dan kehidupannya. Konsep diri juga merupakan landasan dasar untuk dapat menyesuaikan diri. Dengan kata lain, konsep diri merupakan hal yang sangat mempengaruhi penyesuaian diri dan merupakan faktor penting dalam perkembangan diri seseorang. Konsep diri bukan merupakan faktor yang dibawa sejak lahir, melainkan faktor yang dijiwai dan terbentuk melalui pengalaman individu dalam berhubungan dengan orang lain. Dalam berinteraksi ini setiap individu akan menerima tanggapan. Tanggapan yang diterima tersebut akan dijadikan cermin bagi individu untuk menilai dan memandang dirinya sendiri. Jadi konsep diri terbentuk karena suatu proses umpan balik dari individu lain.

Menurut Elizabeth Hurlock (2001: 58), konsep diri adalah gambaran yang dimiliki orang tentang dirinya". Lebih lanjut lagi Burn (1993:i) mengatakan bahwa konsep diri adalah "gambaran campuran dari apa yang kita pikirkan, orang-orang berpendapat mengenai diri kita, dan seperti apa diri kita yang kita inginkan". Konsep diri meliputi apa yang seseorang pikirkan dan rasakan tentang dirinya. Karena itu, Anita Taylor seperti dikutip Rakhmat (2003: 100) mendefinisikan konsep diri sebagai "All you think and feel about you, the entire complex of beliefs and attitudes you hold about yourself." Solomon (2004:150) berpendapat bahwa:

"The self-concept refers to the beliefs a person holds about his or her own attributes, and how he or she evaluates these qualities. Although one's overall selfconcept may be positive, there certainly are parts of the self that are evaluated more positively than other".

Adanya struktur, peran dan status sosial yang menyertai seluruh perilaku individu dipengaruhi oleh faktor sosial. Adanya pengaruh faktor sosial terhadap perkembangan konsep diri individu telah dibuktikan oleh Rosenberg (Pudjijogyanti, 1988). Dijelaskan bahwa perkembangan konsep diri tidak terlepas dari pengaruh faktor sosial, agama, ras. Dijelaskanbahwa individu yang berstatus sosial yang tinggi akan mempunyai konsep diri yang lebih positif dibandingkan individu yang berstatus sosial rendah. Individu dewasa mengalami kesulitan untuk menggabungkan diri dengan satu kelompok sosial tertentu yang cocok dengan dirinya. Salah satu tugas perkembangan yang harus dilakukanolehindividu dewasaadalah menjadibagiandari satu kelompok sosial tertentu.

Berdasarkan paparan di atas, maka penulis merasa perlu untuk meneliti, dengan tujuan untuk menemukan secara empiris tentang pengaruh variabel konsep diri, sikap siswa pada matemati- 
ka dan kecemasan terhadap hasil belajar matematika.

\section{METODE}

Penelitian ini merupakan penelitian survei dengan pendekatan kuantitatif, dimana peneliti berusaha menggambarkan fenomena yang terjadi berdasarkan data yang diambil dari responden menggunakan instrumen yang telah divalidasi sebelumnya. Penelitian ini diadakan di wilayah DKI Jakarta, jenjang pendidikan yang diteliti adalah Sekolah Menengah Pertama. Teknik sampling yang digunakan adalah menggunakan cluster random sampling, di mana diambil sekolah-sekolah secara acak dari pembagian wilayah di DKI Jakarta. Jumlah sampel yang diambil sebanyak 100 siswa.

Data yang digunakan adalah data primer dan data sekunder. Data primer meliputi 3 variabel yang dikumpulkan dengan instrumen yang sebelumnya divalidasi, yaitu: instrumen untuk mengukur Konsep Diri (terbagi dalam indikator persepsi karakteristik fisik, psikologis dan sosial) dengan jumlah 34 butir pernyataan, Kecemasan (terbagi dalam indikator perubahan gejala emosional, perubahan psikologis, perubahan aktivitas fisik dan menghindari tempat atau situasi tertentu) dengan jumlah 30 butir pernyataan dan Sikap Siswa pada Matematika (terbagi dalam indikator perasaan terhadap matematika, kesediaan untuk mempelajari, dan kesadaran terhadap manfaat matematika) dengan jumlah 30 butir pernyataan, sedangkan data tentang hasil belajar matematika diperoleh dari dokumentasi guru sebagai data sekunder.
Mengingat penelitian ini adalah penelitian survei, maka langkah penelitian yang peneliti lakukan adalah perancangan instrumen penelitian dan validasi instrumen. Hal ini dilakukan karena dalam penelitian survei, kehadiran peneliti tidak merupakan kewajiban, sehingga instrumen yang valid dan reliabel merupakan keharusan agar data yang diperoleh benar-benar menunjukkan keadaan yang sebenarnya. Selanjutnya, instrumen yang telah divalidasi tersebut disebarkan kepada responden, untuk kemudian hasilnya ditabulasi dan dianalisis. Data yang telah diperoleh selanjutnya diujipersyaratan analisis datanya, yaitu uji normalitas dan uji linieritas, kemudian selanjutnya diadakan uji hipotesis, dimana analisis data yang digunakan adalah dengan menggunakan analisis jalur, dengan ketentuan sebuah jalur dikatakan signifikan jika nilai koefisien jalurnya $>0,05$.

Untuk memberikan gambaran yang jelas, maka dapat digambarkan konstelasi masalah penelitian ini sebagai berikut.

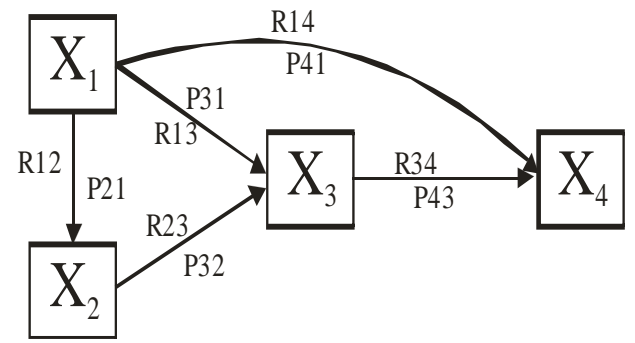

Gambar 1. Desain Penelitian

$X_{1}$ : Konsep Diri

$\mathrm{X}_{2}$ : Sikap Siswa pada Matematika

$X_{3}$ : Kecemasan Siswa

$\mathrm{X}_{4}$ : Hasil Belajar Matematika Siswa 
HASIL PENELITIAN

DESKRIPSI DATA HASIL PENGUKURAN

Data yang telah dikumpulkan berikutnya disajikan dalam tabel distribusi frekuensi di bawah ini.

Tabel 1. Distribusi Frekuensi Variabel Konsep Diri

\begin{tabular}{cccc}
\hline \multicolumn{2}{c}{ Interval } & f & fkum \\
\hline $62-69$ & 7 & 7 \\
$70-77$ & 6 & 13 \\
$78-85$ & 48 & 61 \\
$86-93$ & 28 & 89 \\
$94-101$ & 7 & 96 \\
$102-109$ & 4 & 100 \\
Jumlah & 100 & \\
\hline
\end{tabular}

Tabel 2. Distribusi Frekuensi Variabel Sikap Siswa pada Matematika

\begin{tabular}{cccc}
\hline \multicolumn{2}{c}{ Interval } & f & fkum \\
\hline $59-66$ & 31 & 31 \\
$67-74$ & 16 & 47 \\
$75-82$ & 35 & 82 \\
$83-90$ & 1 & 83 \\
$91-98$ & 17 & 100 \\
\hline Jumlah & 100 & \\
\hline
\end{tabular}

Tabel 3. Distribusi Frekuensi Variabel

Kecemasan Siswa

\begin{tabular}{cccc}
\hline \multicolumn{2}{c}{ Interval } & f & fkum \\
\hline 37 & -44 & 31 & 31 \\
$45-52$ & 7 & 38 \\
$53-60$ & 39 & 77 \\
$61-68$ & 19 & 96 \\
$69-76$ & 4 & 100 \\
\hline \multicolumn{2}{c}{ Jumlah } \\
\hline
\end{tabular}

Tabel 4. Distribusi Frekuensi Variabel Hasil Belajar Matematika

\begin{tabular}{|c|c|c|c|}
\hline \multicolumn{2}{|c|}{ Interval } & $\mathrm{f}$ & fkum \\
\hline & - 67 & 32 & 32 \\
\hline 68 & - $\quad 75$ & 44 & 76 \\
\hline & - 83 & 12 & 88 \\
\hline 84 & - 91 & 12 & 100 \\
\hline 92 & - 99 & 0 & 100 \\
\hline \multicolumn{2}{|c|}{ Jumlah } & 100 & \\
\hline
\end{tabular}

Data yang telah dikumpulkan kemudian ditampilkan secara deskriptif dalam Tabel 5 di bawah ini.

Tabel 5. Statistik Deskriptif

\begin{tabular}{|c|c|c|c|c|c|}
\hline & & Konsep Diri & Sikap & Kecemasan & HBM \\
\hline \multirow[t]{2}{*}{$\mathrm{N}$} & Valid & 100 & 100 & 100 & 100 \\
\hline & Missing & 0 & 0 & 0 & 0 \\
\hline Mean & & 84,1200 & 75,1100 & 53,7600 & 71,2100 \\
\hline Median & & 83,0000 & 77,5000 & 55,0000 & 70,0000 \\
\hline Mode & & 82,00 & 81,00 & 55,00 & 70,00 \\
\hline Std. Deviation & & 7,80350 & 10,75052 & 10,58026 & 7,77858 \\
\hline Variance & & 60,895 & 115,574 & 111,942 & 60,506 \\
\hline Minimum & & 62,00 & 59,00 & 37,00 & 60,00 \\
\hline Maximum & & 103,00 & 92,00 & 76,00 & 90,00 \\
\hline Sum & & 8412,00 & 7511,00 & 5376,00 & 7121,00 \\
\hline
\end{tabular}


Dari tabel di atas tergambar bahwa secara deskriptif, konsep diri responden tergolong baik, hal ini terlihat dari nilai mean dan modus yang hanya sedikit lebih kecil dibandingkan dengan ratarata. Sikap siswa pada matematika juga memiliki kecenderungan positif, terlihat dari nilai mean dan modus yang berada di atas rata-rata, begitupula kecemasan siswa, tergolong dalam kategori kecemasan sedang, terlihat dari skor kese- luruhan yang kecil dan terakhir hasil belajar matematika tergolong dalam kategori cukup, hal ini terlihat dari besar mean dan media yang berada sedikit di bawah nilai rata-rata.

\section{UJI PERSYARATAN ANALISIS}

Sebagai syarat untuk melanjutkan analisis data, maka perlu dilakukan uji kenormalan data, hasilnya sebagai berikut.

Tabel 6. Hasil Uji Normalitas

\begin{tabular}{llrrrr}
\hline & & Konsep Diri & Sikap & Kecemasan & HBM \\
\hline $\mathrm{N}$ & & 100 & 100 & 100 & 100 \\
Normal Parameters & Mean & 84,1200 & 75,1100 & 53,7600 & 71,2100 \\
& Std. Deviation & 7,80350 & 10,75052 & 10,58026 & 7,77856 \\
Most Extreme & Absolute &, 215 &, 141 &, 157 &, 162 \\
Differences & Positive &, 137 &, 126 &, 155 &, 162 \\
& Negative &,- 215 &,- 141 &, 157 &,- 098 \\
Kolmogorov-Smirnov Z & 2,146 & 1,413 & 1,566 & 1,618 \\
Asymp. Sig. (2-tailed) & .000 &, 037 &, 015 &, 011 \\
\hline
\end{tabular}

a. Tes distribution is normal

b. Calculated from data

Dari tabel hasil perhitungan dengan menggunakan SPSS di atas, terlihat bahwa nilai signifikansi secara keseluruhan $<0,05$, sehingga dapat dikatakan bahwa data tidak berdistribusi normal. Untuk itu, untuk analisis selanjutnya akan digunakan teknik statistik nonparametrik untukmenentukan koefisien korelasi antarvariabel.

\section{KORELASI KENDAL'S TAU}

Mengingat data yang tidak berdistribusi normal, maka untuk menghitung besar korelasi antar variabel digunakan Korelasi Kendal's Tau, yang hasilnya sebagai berikut.

Tabel 7. Rekapitulasi Perhitungan Korelasi Kendal's Tau

\begin{tabular}{ccccc}
\hline Korelasi & $\mathrm{X}_{1}$ & $\mathrm{X}_{2}$ & $\mathrm{X}_{3}$ & $\mathrm{X}_{4}$ \\
\hline $\mathrm{X}_{1}$ & 1 & 0,074 & $-0,046$ & 0,076 \\
$\mathrm{X}_{2}$ & 0,074 & 1 & $-0,008$ & 0,047 \\
$\mathrm{X}_{3}$ & $-0,046$ & 0,076 & 1 & $-0,052$ \\
$\mathrm{X}_{4}$ & $-0,008$ & 0,047 & $-0,052$ & 1 \\
\hline
\end{tabular}


Dengan menggunakan konsep persamaan linier yang diselesaikan dengan matriks, diperoleh koefisien-koefisien jalur yang dapat dinyatakan dalam gambar diagram jalur di bawah ini.

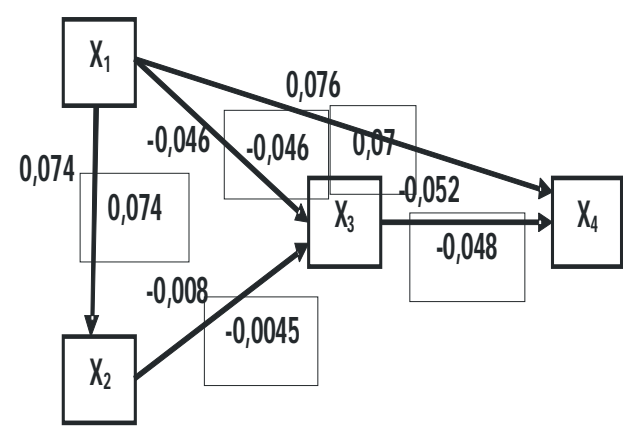

Gambar 2. Diagram Jalur

\section{UJI HIPOTESIS PENELITIAN (ANA- LISIS INFERENSIAL)}

Indeks Path coefficient/path weight pada umumnya adalah koefisien regresi yang distandarkan (artinya regresi di mana semua variabelnya dalam bentuk z-score). Disturbance terms adalah residual error yang besarannya sama dengan (1-R2). Ini mengukur sisa pengaruh faktor lain kepada suatu variabel exogen. Significance and Goodness of Fit. Testing setiap koefisien dengan t-tes atau F-test. Untuk test kecocokan suatu model dengan jika Chi-square dg $\mathrm{P}>0.05$ dan RMSEA < 0.05. Hox dan Bechger (2002) menyebutkan Goodness of fit (Tuna Cocok) dengan chi squared dengan $p$-value lebih besar dari 0.05 persen baru dikatakan model SEM cocok pada data empiris. (Leonard, 2009).

Kriteria pengujian hipotesis secara umum adalah sebuah jalur atau kombinasi beberapa jalur dikatakan signifikan jika dan hanya jika nilai koefisien jalur tersebut di atas 0,05 .

\section{UJI HIPOTESIS 1}

$\mathrm{H}_{0}$ : tidak ada pengaruh langsung antara konsep diri terhadap hasil belajar matematika.

$\mathrm{H}_{1}$ : ada pengaruh langsung antara konsep diri terhadap hasil belajar matematika

Dari diagram di atas, terlihat bahwa koefisien korelasi antara $X_{1}$ dan $X_{4}$ sebesar 0,076 dan koefisien pengaruh $\left(\mathrm{P}_{41}\right)$ sebesar 0,07; sehingga dapat disimpulkan: Tolak $H_{0}$ dan terima $H_{1}$ karena $P_{41}>0,05$. Atau dengan kata lain jalur dari $X_{1}$ ke $X_{4}$ signifikan.

\section{UJI HIPOTESIS 2}

$\mathrm{H}_{0}$ : tidak ada pengaruh tidak langsung antara konsep diri terhadap hasil belajar matematika melalui kecemasan.

$\mathrm{H}_{1}$ : ada pengaruh tidak langsung antara konsep diri terhadap hasil belajar matematika melalui kecemasan.

Dari diagram di atas terlihat bahwa koefisien korelasi antara $X_{1}$ dan $X_{3}$ sebesar -0,046 dan koefisien pengaruh $\left(\mathrm{P}_{31}\right)$ sebesar -0,046; serta koefisien korelasi antara $\mathrm{X}_{3}$ dan $\mathrm{X}_{4}$ adalah $-0,052$ dan koefisien pengaruh $\left(\mathrm{P}_{43}\right)$ sebesar $-0,048$; sehingga didapat koefisien pengaruh tidak langsung antara $X_{1}$ terhadap $X_{4}$ melalui $\mathrm{X}_{3}$ :

$P_{31} \cdot P_{43}=(-, 0,046) \cdot(-0,052)=0,002392$

Sehingga dapat disimpulkan bahwa: Terima $\mathrm{H}_{0}$ dan tolak $\mathrm{H}_{1}$ karena $P_{31 . P_{43}}<$ 0,05 .

Atau dengan kata lain jalur dari $\mathrm{X}_{1} \mathrm{ke}_{4}$ melalui $X_{3}$ non-signifikan. 


\section{UJI HIPOTESIS 3}

$\mathrm{H}_{0}$ : tidak ada pengaruh tidak langsung antara sikap terhadap hasil belajar matematika melalui kecemasan.

$\mathrm{H}_{1}$ : ada pengaruh tidak langsung antara sikap pada Matematika terhadap hasil belajar matematika melalui kecemasan

Dari diagram di atas terlihat bahwa koefisien korelasi antara $X_{2}$ dan $X_{3}$ sebesar -0,008 dan koefisien pengaruh ( $\left.\mathrm{P}_{32}\right)$ sebesar -0,0045; serta koefisien korelasi antara $\mathrm{X}_{3}$ dan $\mathrm{X}_{4}$ adalah -0,052 dan koefisien pengaruh $\left(\mathrm{P}_{43}\right)$ sebesar $-0,048$; sehingga didapat koefisien pengaruh tidak langsung antara $X_{2}$ terhadap $X_{4}$ melalui $\mathrm{X}_{3}$ :

$\mathrm{P}_{32} \cdot \mathrm{P}_{43}=(-, 0,0045) \cdot(-0,052)=0,000234$

Sehingga dapat disimpulkan bahwa: Terima $\mathrm{H}_{0}$ dan tolak $\mathrm{H}_{1}$ karena $P_{32 .} P_{43}<$ 0,05 .

Atau dengan kata lain jalur dari $\mathrm{X}_{2} \mathrm{ke}_{4}$ melalui $X_{3}$ non-signifikan.

\section{UJI HIPOTESIS 4}

$\mathrm{H}_{0}$ : tidak ada pengaruh langsung antara kecemasan terhadap hasil belajar matematika.

$\mathrm{H}_{1}$ : ada pengaruh langsung antara kecemasan terhadap hasil belajar matematika.

Dari diagram di atas terlihat bahwa koefisien korelasi antara $\mathrm{X}_{3}$ dan $\mathrm{X}_{4}$ adalah $-0,052$ dan koefisien pengaruh (P43) sebesar -0,048; sehingga dapat disimpulkan: Terima $\mathrm{H}_{0}$ dan tolak $\mathrm{H}_{1}$ karena $P_{41}<0,05$. Atau dengan kata lain jalur dari $\mathrm{X}_{3}$ ke $\mathrm{X}_{4}$ non-signifikan.

\section{UJI HIPOTESIS 5}

$\mathrm{H}_{0}$ : tidak ada pengaruh langsung antara konsep diri terhadap sikap pada Matematika.

$\mathrm{H}_{1}$ : ada pengaruh langsung antara konsep diri terhadap sikap pada Matematika.

Dari diagram di atas terlihat bahwa koefisien korelasi antara $X_{1}$ dan $X_{2}$ sebesar 0,074 dan koefisien pengaruh $\left(\mathrm{P}_{21}\right)$ sebesar 0,074; sehingga dapat disimpulkan: Tolak $H_{0}$ dan terima $H_{1}$ karena $P_{21}>0,05$. Atau dengan kata lain jalur dari $X_{1}$ ke $X_{2}$ signifikan.

\section{PEMBAHASAN}

Hasil perhitungan dalam hipotesis 1 memberikan hasil signifikan, walaupun nilainya tidak terlalu besar akan tetapi hal ini membuktikan bahwa ada pengaruh positif dan signifikan antara konsep diri siswa terhadap hasil belajar matematika siswa. Dengan kata lain, siswa yang memiliki kepercayaan diri dan persepsi serta cara pandang yang positif tentang dirinya sendiri akan mampu meningkatkan hasil belajar matematika. Persepsi dan cara pandang tersebut perlu dibangundan dikembangkan, baik secara internal maupun eksternal, sehingga sudah seharusnya siswa secara pribadimenghargaiseluruh aspek kehidupannya, serta sudah seharusnya juga seluruh elemen di luar diri siswa (termasuk guru, kepala sekolah, orang tua dan masyarakat) memberikan penghargaan dan apresiasi yang optimal sehingga siswa dapat membangun konsep diri yang positif.

Hasil perhitungan dalam hipotesis 2 memberikan hasil nonsignifikan, yang artinya tidak ada pengaruh positif dan 
signifikan antara konsep diri terhadap hasil belajar matematika melalui kecemasan siswa. Di sisi lain, bila diperhatikan secara parsial ternyata konsep diri juga tidak berpengaruh positif dan signifikan terhadap kecemasan siswa, yang artinya semakin baik konsep diri siswa, maka siswa akan semakin mampu untuk mengontrol tingkat kecemasannya. Atau, semakin baik konsep diri, maka semakin rendah tingkat kecemasan siswa. Di bagian berikutnya, secara parsial juga ternyata kecemasan siswa juga tidak berpengaruh positif dan signifikan terhadap hasil belajar siswa, yang artinya semakin tinggi kecemasan siswa, maka semakin rendah hasil belajar matematika siswa, sehingga secara keseluruhan dapat dikatakan bahwa konsep diri tidak memberikan pengaruh positif terhadap hasil belajar jika melalui kecemasan siswa.

Hasil perhitungan dalam hipotesis 3 memberikan hasil nonsignifikan, yang artinya tidak ada pengaruh positif dan signifikan antara sikap siswa pada matematika terhadap hasil belajar matematika melalui kecemasan siswa. Di sisi lain, bila diperhatikan secara parsial ternyata sikap siswa pada matematika juga tidak berpengaruh positif dan signifikan terhadap kecemasan siswa. Artinya, semakin baik sikap siswa pada matematika, siswa akan semakin mampu untuk mengontrol tingkat kecemasannya. Atau, semakin baik sikap siswa pada matematika, maka semakin rendah tingkat kecemasan siswa. Di bagian berikutnya, secara parsial juga ternyata kecemasan siswa juga tidak berpengaruh positif dan signifikan terhadap hasil belajar siswa. Artinya, semakin tinggi ke- cemasan siswa, semakin rendah hasil belajar matematika siswa, sehingga secara keseluruhan dapat dikatakan bahwa sikap siswa pada matematika tidak memberikan pengaruh positif terhadap hasil belajar jika melalui kecemasan siswa.

Hasil perhitungan dalam hipotesis 4 memberikan hasil nonsignifikan. Artinya, tidak ada pengaruh positif dan signifikan antara kecemasan siswa terhadap hasil belajar matematika. Hasil ini membuktikan kecemasan siswa tidak memberikan pengaruh bagi peningkatan hasil belajar matematika. Dengan kata, lain semakin tinggi kecemasan siswa maka semakin rendah hasil belajar matematikanya dan sebaliknya semakin rendah kecemasan siswa, semakin tinggi hasil belajar matematika siswa. Atau di bagian lain, penelitian ini berhasil menemukan bahwa terdapat pengaruh negatif kecemasan terhadap hasil belajar matematika, sehingga siswa yang mampu mengontrol tingkat kecemasannya akan berhasil dalam belajar matematika.

Hasil perhitungan dalam hipotesis 5 memberikan hasil signifikan. Walaupun nilainya tidak terlalu besar, namun hal ini membuktikan bahwa ada pengaruh positif dan signifikan antara konsep diri siswa terhadap sikap siswa pada matematika. Dengan kata lain, siswa yang memiliki kepercayaan diri dan persepsi serta cara pandang yang positif tentang dirinya sendiri akan mampu memperbaiki sikapnya pada matematika. Persepsidan cara pandang tersebut perlu dibangun dan dikembangkan, baik secara internal maupun eksternal, sehingga sudah seharusnya siswa secara pribadi 
menghargai seluruh aspek kehidupannya. Selain itu, sudah seharusnya seluruh elemen di luar diri siswa (termasuk guru, kepala sekolah, orang tua dan masyarakat) memberikan penghargaan dan apresiasi yang optimal sehingga siswa dapat membangun konsep diri yang positif.

\section{KESIMPULAN}

Hipotesis 1 dinyatakan signifikan, yang artinya ada pengaruh positif dan signifikan antara konsep diri siswa terhadap hasil belajar matematika siswa. Dengan kata lain, siswa yang memiliki kepercayaan diri dan persepsi serta cara pandang yang positif tentang dirinya sendiri akan mampu meningkatkan hasilbelajar matematika. Hipotesis 2dinyatakan nonsignifikan. Artinya, tidak ada pengaruh positif dan signifikan antara konsep diri terhadap hasil belajar matematika melalui kecemasan siswa. Hipotesis 3 dinyatakan nonsignifikan, yang artinya tidak ada pengaruh positif dan signifikan antara sikap siswa pada matematika terhadap hasil belajar matematika melalui kecemasan siswa. Hipotesis 4 dinyatakan nonsignifikan, yang artinya tidak ada pengaruh positif dan signifikan antara kecemasan siswa terhadap hasil belajar matematika. Hasil ini membuktikan kecemasan siswa tidak memberikan pengaruh bagi peningkatan hasil belajar matematika. Hipotesis 5 dinyatakan signifikan, walaupun nilainya tidak terlalu besar, tetapi hal ini membuktikan bahwa ada pengaruh positif dan signifikan antara konsep diri siswa terhadap sikap siswa pada matematika. Atau dengan kata lain, siswa yangmemilikikepercayaan diri dan per- sepsi serta cara pandang yang positif tentang dirinya sendiri akan mampu memperbaiki sikapnya pada matematika.

\section{SARAN}

Siswa sebagai individu harus berusaha menghargai hidup dan kehidupannya, termasuk potensi yang dimilikinya sehingga dapat memiliki kepercayaan diri dalam menghadapi tantangan ke depan. Guru, kepala sekolah, orang tua dan masyarakat sebagai orang terdekat siswa juga harus berusaha memberikan penghargaan yang cukup kepada siswa dalam rangka peningkatan konsep diri siswa yang dampaknya akan meningkatkan hasil belajar matematika siswa. Guru sebagai unsur terdepan dalam proses pembelajaran harus memperhatikan tingkatkecemasan siswa. Dengan kata lain, guru harus dapat mengarahkan siswa agar mampu mengontrol tingkat kecemasannya, sehingga dampaknya dapat meningkatkan hasil belajar matematika siswa.

Seluruh elemen pendidikan, siswa, orang tua, guru dan pemerintah harus mengupayakan agar siswa memiliki sikap yang positif terhadap matematika, karena dengan memiliki sikap yang positif terhadap matematika diharapkan dapat meningkatkan hasil belajar matematika.Seluruh elemen pendidikan juga dapatmengontroltingkat kecemasan siswa, artinya siswa tidak boleh diberikan situasi atau keadaan yang dapat meningkatkan kecemasannya karena dampaknya akan menurunkan hasil belajar matematika.Siswa dan guru harus mampu mengembangkan suasana pendidikan yang kondusif, tempat siswa mampu 
meningkatkan konsep dirinyayang pada akhirnya mampu membangkitkan sikap yang positif terhadap matematika.

\section{UCAPAN TERIMA KASIH}

Dalam penulisan artikel ini, penulis sangat dibantu oleh banyak pihak, baik secara moril maupun materiil. Untuk itu, dalam kesempatan ini penulis menyampaikan ucapan terima kasih kepada: Prof. Dr. H. Sumaryoto (Rektor UNINDRA), Drs. Supardi U.S., MM., M.Pd. (Dekan FTMIPA UNINDRA), Dr. H. Suparman I.A. (Direktur PPs UNINDRA), Prof. Dr. Sasmoko, M.Pd., Renita Simamora dan Kevin Sundobasana Simangunsong.

\section{DAFTAR PUSTAKA}

Azwar, Saifuddin. 1998. Sikap Manusia: Teori dan Pengukurannya. Yogyakarta: Pustaka Pelajar.

Biggs, John B. \& Philip J. Moore. 1983. Process of Learning. Third Edition. New York: Prentice Hall.

Burns, R.B. 1993. Konsep Diri: Teori, Pengukuran, Perkembangan dan Perilaku. Jakarta: Arcan.

Gibson, James L., John M. Ivancerich dan Jarnes H. Donneily. 1990. Organisasi. Terjemahan: Djarkasih. Jakarta: Erlangga.

Hurlock, Elizabeth B. 2001. Perkembangan Anak, Jilid 2. Jakarta: Erlangga.
Kertonegoro, Sentanoe. 1997. Perilaku di Tempat Kerja. Jakarta: Yayasan Tenaga Kerja Indonesia.

Kifli, Buchori dan Mustofa, Usman. 1985. Prinsip-Prinsip Matematika. Bandung: Sinar Baru.

Leonard. 2009. Pengenalan Path Analysis \& SEM. http:/wwww.leoriset.blogspot.com, 11 Januari 2010.

Luthans, Fred. 2005. Perilaku Organisasi, Terjemahan: Vivin AY dan Shekar P. Yogyakarta: Penerbit Andi.

Mar'at. 1981. Sikap Manusia: Perubahan Serta Pengukurannya. Jakarta. Ghalia Indonesia.

Pudjijogyanti, Clara R. 1988. Konsep Diri dalam Pendidikan. Jakarta: Penerbit Arcan.

Rakhmat, Jalaludin. 2003. Psikologi Komunikasi. Bandung: Remaja Rosda Karya.

Rasyad, Aminudin. 2003. Teori Belajar dan Pembelajaran. Cet. Ke-4. Jakarta: UHAMKA Press \& Yayasan PEP-Ex 8.

Robbins, Stephen P. 2006. Perilaku Organisasi. Terjemahan: Benyamin Molan. Jakarta: Indeks.

Solomon, Michael R. 2004. Consumer Behavior: Buying, Having and Being. USA: Prentice Hall.

Supardi dan Leonard. 2009. "Kebijakan Sekolah Gratis Ditinjau dari Pres- 
tasi Belajar dengan Mengontrol Kemampuan Awal Siswa", Sosioekons, Volume I Nomor 3, hal. 6480 .

Suparman I.A., 2006, "Matematika Sebagai Dasar Semua Ilmu", Makalah, Orasi Ilmiah Wisuda Sarjana XVIII UNINDRA PGRI. Jakarta: Unindra.

Suryabrata, Sumadi. 2004. Psikologi Pendidikan. Jakarta: PT. Raja Grafindo Persada.

Winkel, W.S. 1996. Psikologi Pengajaran. Jakarta. Grasindo. 